\title{
PROPORTION OF FAMILIES SERVED BY A FAMILY DOCTOR
}

\author{
BY \\ JOHN S. OWEN \\ From the Public Health Department, Smethwick, Staffs.
}

Conversation with mothers of young children attending Infant Welfare Centres in Smethwick revealed a surprisingly large number who stated that they were registered with a different doctor from their husbands. It was felt that an investigation of the proportion of families served by one general practitioner would be worth while in view of the prominence given to the "family" doctor in current discussions of the medical service.

\section{MATERIAL}

During an 18-month period in 1951-52, 315 mothers seen by the medical officer at two of Smethwick County Borough's Infant Welfare Centres, were questioned about their medical attendants. No attempt was made to question every mother who attended the centres, but, during this period, most of them had occasion to consult the medical officer, and each was then asked the name of the doctor with whom each member of the family was registered. Latterly, enquiries were also made regarding the doctors attending husband and wife before marriage. The information given could be regarded as accurate, but, occasionally, a wife could not remember the name of her husband's doctor.

Most mothers attending the centres were drawn from working class families and were in the age group 20-35 years.

\section{RESULTS}

Of the 315 mothers questioned, ten have been omitted from the survey, either because the husband was in the armed forces or because he had not registered with any doctor. The examination relates, therefore, to 305 families.
Of these 305 families, 153 (50.2 per cent.) had a family doctor, that is to say husband, wife, and children were all registered with the same medical practitioner (Table I); 152 (49.8 per cent.) had no family doctor, but of these families $22(7 \cdot 2$ per cent.) were registered with different doctors in the same partnership. In Smethwick the majority of the general practitioners are in partnerships of two or three; so that, in a limited sense, these families could claim to possess a family doctor. This leaves 130 families ( 42.6 per cent.) who had no family doctor in any sense of the term.

TABLE I

PROPORTION OF FAMILIES SERVED BY ONE OR MOR\& GENERAL PRACTITIONERS

\begin{tabular}{|c|c|c|c|c|c|}
\hline & & \multirow[b]{2}{*}{ One } & \multicolumn{2}{|c|}{ Two or More Doctors } & \\
\hline \multicolumn{2}{|c|}{ Doctor } & & $\underset{\text { Partnership }}{\text { In }}$ & $\begin{array}{c}\text { Not in } \\
\text { Partnership }\end{array}$ & Total \\
\hline \multirow{2}{*}{ Families } & Per cent. & $50 \cdot 2$ & $7 \cdot 2$ & $42 \cdot 6$ & 100 \\
\hline & Number & 153 & 22 & 130 & 305 \\
\hline
\end{tabular}

The medical attendance in these 130 families is shown in Table II. Eleven families claimed the services of three doctors; each parent had a different doctor and a third doctor looked after the children. In 107 families the children were registered with the mother's doctor. This is, perhaps, to be expected, since the mother is usually responsible for taking an ailing child to the doctor's surgery or for asking for a domiciliary visit. In only seven families were the children registered with the father's doctor.

TABLE II

MEDICAL ATTENDANCE IN FAMILIES SERVED BY TWO OR MORE GENERAL PRACTITIONERS NOT IN PARTNERSHIP

\begin{tabular}{|c|c|c|c|c|c|c|c|}
\hline \multicolumn{2}{|c|}{ Husband and Wife } & \multicolumn{4}{|c|}{ With different Doctors } & \multirow{2}{*}{$\begin{array}{c}\text { With same Doctor } \\
\begin{array}{c}\text { With a Different } \\
\text { Doctor }\end{array}\end{array}$} & \multirow[b]{2}{*}{ Total } \\
\hline \multicolumn{2}{|c|}{ Children } & $\begin{array}{l}\text { With Father's } \\
\text { Doctor }\end{array}$ & $\begin{array}{c}\text { With Mother's } \\
\text { Doctor }\end{array}$ & $\begin{array}{l}\text { Some with Father's } \\
\text { some with Mother's } \\
\text { Doctor }\end{array}$ & $\begin{array}{l}\text { With a Third } \\
\text { Doctor }\end{array}$ & & \\
\hline Per cent. .. & $\cdots$ & $5 \cdot 4$ & $82 \cdot 3$ & $1 \cdot 5$ & $8 \cdot 5$ & $2 \cdot 3$ & 100 \\
\hline Number .. & $\cdots$ & 7 & 107 & 2 & 11 & 3 & 130 \\
\hline
\end{tabular}


TABLE III

MEDICAL ATTENDANCE IN FAMILIES SERVED BY ONE GENERAL PRACTITIONER

\begin{tabular}{|c|c|c|c|c|c|c|c|}
\hline \multicolumn{3}{|c|}{ Changes after Marriage } & $\begin{array}{l}\text { Wife changed to } \\
\text { Husband's Doctor }\end{array}$ & $\begin{array}{l}\text { Husband changed to } \\
\text { Wife's Doctor }\end{array}$ & $\begin{array}{l}\text { Both changed to } \\
\text { Different Doctor } \\
\text { after Marriage }\end{array}$ & $\begin{array}{c}\text { No Change } \\
\text { (Both had Same } \\
\text { Doctor before } \\
\text { Marriage) }\end{array}$ & Total \\
\hline Number & $\ldots$ & $\ldots$ & $26 \cdot 4$ & $24 \cdot 5$ & $38 \cdot 7$ & $10 \cdot 4$ & 100 \\
\hline Per cent. & $\ldots$ & .. & 28 & 26 & 41 & 11 & $106 *$ \\
\hline
\end{tabular}

* 47 of the 153 families served by one general practitioner have been excluded because information was incomplete.

In the remaining five families one or more children had a different doctor from the parents or one child was under the father's doctor and one under the mother's doctor.

Information regarding the 153 families served by a family doctor is incomplete, since, at the beginning of the survey, questioning did not include details of medical attendants before marriage. Information about 106 of these families, however, is available (Table III). In 26 cases the husband changed to the wife's doctor on marriage; in 28 cases the wife changed to the husband's doctor; in 41 cases both partners changed to a new doctor. In eleven cases both husband and wife had the same doctor before and after marriage. Further information would be required before much significance could be attached to these figures.

\section{Discussion}

This survey relates to a selected group of families in a densely populated urban area. The finding that only half the families possess a family doctor is of interest, but may not be a true reflection of the situation throughout Great Britain. In a rural community, for example, one imagines that nearly everyone is registered with the same doctor, usually because he is the only doctor in the area; and in a well-to-do residential district the proportion of families served by a family doctor is also likely to be higher.

The commonest finding among the 152 families not possessing a family doctor is that the mother and father have different doctors, and that each keeps the doctor with whom he or she was registered before marriage. When children are born they are usually registered with the mother's doctor.

It was not possible to enquire in detail about motives governing choice of practitioner. Only two mothers volunteered the information that they thought it desirable to have a family doctor. Mothers with young children often stated that they had changed to a particular doctor because he was interested in children. In some cases the choice of doctor seemed quite haphazard. For example a man who came from Ireland to join his family attempted to consult his wife's practitioner, but finding he was not available crossed the road and became registered with another doctor.

\section{SUMMARY}

When 305 mothers attending welfare clinics were questioned, it was found that in only half the related families were all members registered with the same general practitioner. 